Manuscript in press to be published in European Journal of Psychology of Education. 2010.25(2): 207-221. "The final publication is available at Springer via http://dx.doi.org/10.1007/s10212-010-0013- $x . "$

Pupils' pedagogical well-being in comprehensive school - Significant positive and negative school experiences of Finnish ninth graders

\title{
Authors
}

Corresponding author:

Kirsi Pyhältö

Centre for Research and Development of Higher Education (YTY)

Faculty of Behavioural Sciences

P.O.BOX 9 (Siltavuorenpenger 20)

FIN-00014 University of Helsinki, Finland

Room 415

+358504150132

kirsi.pyhalto@helsinki.fi

Tiina Soini

Department of Teacher Education

FIN- 33014 University of Tampere, Finland

$+358503501188$

tiina.soini@uta.fi

Janne Pietarinen

Faculty of Education

P.O. BOX 111

FIN-80101 University of Joensuu, Finland

+358504650642

janne.pietarinen@joensuu.fi 


\section{Pupils' pedagogical well-being in comprehensive school - Significant positive and negative school experiences of Finnish ninth graders}

Abstract

Basic education has two main goals: to promote high quality learning outcomes and pupils' personal growth and well-being. The interrelated nature of learning and wellbeing is here referred to as pedagogical well-being. In this study, we explore Finnish comprehensive school pupils' ( $\mathrm{N}=518)$ experienced pedagogical well-being by examining the kinds of situations that pupils themselves find either highly positive or highly negative during their school career. Pupils’ pedagogical well-being is empirically examined in two complementary aspects: 1) determining the point in the pupils' school career in which the critical incidents are situated and 2) identifying the primary contexts of pupils' experienced critical incidents of pedagogical well-being. Results showed that critical incidents for pedagogical well-being reported by the pupils were situated all along their school career. A variety of episodes causing empowerment and satisfaction, as well as disappointment and anxiety, were reported by the pupils. Pupils’ perceived the social interactions within the school community as being the most rewarding as well as the most problematic part of their school career.

Keywords: basic education, comprehensive school, pupil, well-being, learning, pedagogy

\section{Introduction}

Basic education has two main goals: to promote simultaneously high quality learning outcomes and pupils' personal growth and well-being. However, attaining these goals in reality is not easy, nor is it self-evident. Despite Finland's success with regard to pupils' learning outcome comparisons, e.g., in PISA (Program for International Student Assessment), there are some indications of problems with the well-being of pupils in Finland. For instance, signs of earlier social exclusion and a rise in depressive symptoms 
among girls and an increase in negative attitudes towards school among boys have been identified in national surveys of school health issues (Rimpelä, Kuusela, Rigoff, Saaristo, \& Wiss, 2008; Rimpelä, Rigoff, Kuusela, \& Peltonen, 2007). At the same time little is known about how pupils' themselves perceive their school path in terms of this entwined relationship between learning and well-being. In this study, we look at the case of Finnish comprehensive schools as an example of the complexity involved with addressing these dual goals. The article focuses on exploring pupils' experienced pedagogical well-being in comprehensive schools in Finland.

\subsection{Aim of the study}

This study aims to gain better understanding of Finnish $9^{\text {th }}$ graders' pedagogical well-being by examining the kinds of situations that pupils themselves find either highly positive or highly negative during their school career. These situations are seen as critical incidents in which the constructed pedagogical well-being becomes observable. Pupils' pedagogical well-being is empirically examined in two complementary aspects: 1) determining the point in the pupils' school career in which the critical incidents are situated and 2) identifying the primary contexts of pupils' experienced critical incidents of pedagogical well-being.

\subsection{The study context}

This study is part of a larger national research project: "Learning and development in comprehensive school” (2004 - 2009), which focuses on undivided basic education in Finland. The project aims to identify and understand preconditions for successful school reforms. Altogether 87 municipalities and 237 schools around Finland participated in the first phase of the research project (2005-2007). The project was carried out using a systemic design research approach (Brown, 1992; Collins, Joseph, \& Bielaczyc, 2004; De Corte, 2000; Salomon, 1996) and included data collection from four different levels of the schooling system: a) chief of school districts, b) principals, c) teachers and d) pupils ( $9^{\text {th }}$ graders). To capture the views of different actors, the data was collected through mixed methods such as inquiries, interviews, reflective discussion and 
activating methods. The part of the larger study reported here focuses on exploring pupils’ pedagogical well-being.

\subsection{Learning of socio-psychological well-being in school}

In addition to the intended learning outcomes, the pedagogical processes within school communities can generate either feelings of engagement and empowerment and a sense of satisfaction, or feelings of stress and anxiety for the participants of the processes (Boekaerts, 1993; Krapp, 2005; Konu, Lintonen, \& Autio, 2002; Savolainen, 2001; Pelletier, Legault, \& Séquin-Lévesque, 2002; Silins \& Mulford, 2002; Tarter \& Hoy, 2004; Van Houtte, 2006). Construction of socio-psychological well-being for members of the school community can be understood as a learning process that promotes relatedness, competence and autonomy (Deci \& Ryan, 2002; Lazarus \& Lazarus, 1994; Sheldon \& King, 2001; Hakanen, Bakker, \& Schaufeli, 2005; Hakkarainen, Palonen, Paavola, \& Lehtinen, 2004; Krapp, 2005; Seligman \& Csikszentmihalyi, 2000). Learning for sociopsychological well-being within school can be seen as an active, collaborative and situated process in which the relationship between individuals and their environment is constantly constructed and modified. In turn, socio-psychological well-being experienced by the members of the school community regulates their learning in many ways, for example, it can affect the ability to concentrate and observe the environment, perceive affordances and interpret received feedback (Antonovsky, 1987; 1993; Bowen, Richman, Brewster, \& Bowen, 1998; Deci \& Ryan, 2002; Kristersson \& Öhlund, 2005; Morrison \& Clift, 2005; Ryan \& Deci, 2001; Pallant \& Lae, 2002; Torsheim, Aarø, \& Wold, 2001). Hence pupils' sense of engagement and empowerment in studying is regulated by their experienced relationships with peers and teachers, belonging to the class and school community, self-efficacy, and perceived control and agency over one's action. Learning for socio-psychological well-being is not only about acquisition of knowledge and skills, but about an ongoing, interactive process of sense making and development in which motives and emotions play an important part (e.g. Lasky, 2005; Lonka, Hakkarainen, \& Sintonen, 2000; Nonaka \& Nishiguchi, 2001; Paavola \& Hakkarainen, 2005; Wenger, 1998; Wertsch, 1993). 
The quality of pedagogical processes in school can be assessed by examining to what extent they facilitate the preconditions for learning and socio-psychological wellbeing both for pupils and teachers (Butler \& Shibaz, 2008; Retelsdorf, Butler, Streblow, \& Schiefele, 2009). Inexplicably, socio-psychological well-being as perceived by the members of a school community is often generated as an unintended by-product of pedagogical processes and school practices. A sense of autonomy, relatedness, competence and belonging or a lack of these elements generated for pupils as well as teachers in the everyday interactions of school are here referred to as pedagogical wellbeing. The construction of pedagogical well-being could be understood as a process of succeeding cycles of positive or negative learning experiences leading to empowerment and engagement, or in severely negative cases, to exclusion from school activities. Accordingly, pedagogical well-being is constructed in the core processes of school work that is, carrying out and developing pedagogical processes, including studying, classroom activities, and interactions with pupils, teachers and other members of the school community. The experienced pedagogical well-being may either hinder or promote attainment of the pedagogical goals, and it therefore serves as a regulator for attaining learning outcomes.

\subsection{Pupils' pedagogical well-being}

Pedagogical well-being is part of pupils' overall well-being, along with other important elements, such as health and social networks outside the school, particularly relationships with parents, other relatives and friends. However, the major characteristic of pedagogical well-being is that it is generated in the everyday practices of schooling. A pupil may simultaneously experience empowerment, joy and satisfaction in peer interaction along with feelings of anxiety and stress caused by problems in studying. In positive cases the pedagogical well-being generated in the classroom interactions with teachers and peers, for example, may even function as a buffer against the burden and anxiety caused by unsolved problems at home. Therefore pedagogical well-being could be seen as a crucial aspect of pupil's resilience and coping with various kinds of developmental ruptures during their school career (Zittoun, 2008; Zittoun, Duveen, Gillespie, Ivinson, \& Psaltis, 2003). On the other hand in negative cases the action 
orientation and coping strategies adopted by the pupil, such as avoidance or defensive strategies, may gradually cause an inability to connect with the school community, resulting in exclusion from the learning and the protective social-psychological wellbeing generated in class.

Pupils’ pedagogical well-being is entwined with success in studying, which in turn is linked to the ability of the pupil to participate in the learning community and school activities. Characteristic for the types of pedagogical interactions that promote pupils' satisfaction, engagement, and empowerment are participants' perceptions of themselves as active learners and their experience of a sense of coherence, meaningfulness and belonging (Antonovsky, 1987; 1993; Bowen et al., 1998; Torsheim et al., 2001; Pallant \& Lae, 2002; Kristersson \& Öhlund, 2005; Morrison \& Clift, 2005; Deci \& Ryan, 2002; Ryan \& Deci, 2001). Consequently, a precondition for promoting pedagogical well-being is that pupils’ perceive themselves as active subjects belonging to the school community. In contrast, lack of efficacy, feelings of alienation, and inequality are all typical of the interactions that undermine the construction of pedagogical wellbeing. For example if a pupil is feeling dismissed and dominated by the teacher in teaching-learning situations, they are more likely to adopt passive or rigid action strategies than if they feel empowered and appreciated by the teacher. Respectively, more flexible and reflective problem strategies may promote a pupils' sense of empowerment and dialog between pupils and teachers. Hence the manner in which the problematic situation is solved is likely to affect not only the end result of the situation, but also the feedback the pupil receives about themselves and thus their self-image as a student and member of school community (Bowen, Richman, Brewster, \& Bowen, 1998; Gregory \& Ripski, 2008). This in turn further reflects on strategies and practices adopted by the pupil, thus resulting in either positive or negative cycles of experienced pedagogical wellbeing. The kinds of strategies and practices that promote pupil's experienced pedagogical well-being can be learned.

\subsection{Pupils’ pedagogical well-being generated in multiple contexts}

Pupils' pedagogical well-being is constructed in the interaction processes of a school's multilevel learning environment, not only with teachers but also with peers and other 
members of the school community. In order to understand the generation of pupils' pedagogical well-being, some features of the school as a distinctive social, cultural and psychological environment should be discussed.

Schools are complex contexts with multiple levels and practices, some of them contradictory. During their school careers pupils are exposed to various pedagogical subcultures and expectations, they participate in different kinds of peer groups and they adopt various roles in the school's dynamic and complex multilayered community of practice. There are opportunities for agency, avoidance, and opposition and resistance, and as a consequence there is inevitable tension in interactions between different actors in the context (Lahelma, 2002). Transitions in and between these contexts provide different kinds of resources and challenges for constructing pupils' pedagogical well-being (Anderson, Jacobs, Schramm, \& Splittgerber, 2000; Ellonen, Kääriäinen, \& Autio, 2008; Gillison, Standage, \& Skevington, 2008; Jindal-Snape \& Miller, 2008). In fact the critical incidents within the contexts perceived by the pupils may function as triggers for construction of pedagogical well-being.

Teachers and pupils are the core of the school community. However, teachers' and pupils' intentions, orientations and perceptions towards school activities have been found to differ fundamentally. For instance, teachers tend to perceive the classroom environment more positively and more favourably than pupils do (e.g. Hofman, Hofman, \& Guldemond, 2001). In Finland boys especially have been found to perceive their school ambience as poor (Rimpelä, Kuusela, Rigoff, Saaristo, \& Wiss, 2008; Rimpelä, Rigoff, Kuusela, \& Peltonen, 2007). A reason for pupils to perceive the classroom environment more negatively than teachers may be that the concentration on learning outcomes may sometimes override the social aims of school education, for example, if a teacher ignores or does not recognize challenges such as bullying within the pupils' peer group interaction. This is likely to generate tension within the interaction of teachers and pupils and thus affect their experienced pedagogical well-being.

However, there is also an interrelation between teachers' and pupils' orientations towards school work: for instance, if a teacher perceives her work as primarily regulated by demands coming from different stakeholders outside the school community (such as politicians and school administrators), she or he is likely to use more external control and 
this can result in more external strategies of learning for the pupils (Pelletier et al., 2002). It could be argued that a modern school is a context of continuing negotiations between pupils and teachers about authority and meaning making, and that both the ambience of the school community and the achievement of pedagogical goals are to a great extent dependent on the success of the negotiations between these actors (Gregory \& Ripski, 2008; Schweinle, Turner, \& Meyer, 2008; Van Petegem, Aelterman, Rosseel, \& Creemers, 2006).

In addition to the pupil-teacher interaction in schools, pupils' peer interaction is another crucial element of the school as a social environment. Accordingly, there has been a growing interest in peer interaction effects on the whole of school life, pedagogical intentions included (Tuominen-Soini, Salmela-Aro, \& Niemivirta, 2008; Hofer, 2007; Boekaerts, De Koning, \& Vedder, 2006; Giota, 2006; Vedder, Boekaerts, \& Seegers, 2005). Informal interactions and the getting and maintaining of friendships are crucial elements of personal growth and feelings of meaningfulness and belonging, especially for young people. Hence peer interaction may significantly facilitate not just personal growth and socio-psychological well-being but also motivation towards school work. On the other hand, in the pupils' experience expected learning outcomes and personal goals, such as the need to gain social approval from the peer group, may sometimes appear to be in conflict with each other. At its worst this may result in exclusion from the pedagogical aims of school. Accordingly pupil's pedagogical wellbeing is constructed not only in formal instructional settings but also in informal interactions, for instance during breaks and lunch hours (Lahelma, 2002).

To sum up, the complementary contexts of pupils' schooling provide both challenges and opportunities for pupils' pedagogical well-being. There are elements that challenge pupils' engagement and commitment to the school activities, as well as resources for positive studying drive and satisfaction. 
2 Study design

\subsection{Participants}

This study included data collected from six case-schools around Finland. The criteria for selecting the case schools were variation and representativeness of the sample. Both secondary and 1-9 grade comprehensive schools were included in the cases. The schools were of various sizes and phases in their school reform (the Undivided Basic Education development work), and they were situated all around the country (Huusko, Pietarinen, Pyhältö \& Soini, 2007). All the $9^{\text {th }}$ graders from each case school responded to the survey, comprising altogether 518 pupils (Girls: $46 \%$ and Boys: 54\%).

\subsection{Data collection}

The survey of pupils was conducted in six case-schools during spring 2006. The survey embodied questions on four themes: significant (negative and positive) school experiences throughout the school career, interactions with teachers, school development and the problems pupils have faced in their school path. In total the survey contained 10 open-ended questions and 2 questions on background variables. All questions and instructions were validated by the members of the research group before conducting the survey. The data were collected by the researchers during their fieldwork on caseschools. Pupils were given instructions for completing the survey by researchers both in writing and verbally. It took between 30 and 45 minutes to complete the survey. The written responses were collected by the researchers and then the surveys were decoded into text files by two trained research assistants. This article focuses on those questions that addressed pupils' positive and negative school experiences and how these experiences were situated in their school career.

\subsection{Instrument}

In the present study, the $9^{\text {th }}$ graders' perceptions of typical challenges and problems within their school career were explored with the open ended questions: "Describe a significant positive and negative experience during your school path!", "What happened?", "What caused the event?", and "What did you think and feel at the time?" 
Pupils were also asked to put the two types of experiences on the timeframe of their comprehensive school path with the questions: "When did this event take place? Please mark both the highly positive (with +) and the negative (with -) experiences on the timeline that describes your school career from the first to ninth grade below!" In addition the background variable 'gender' was explored to find out whether there were any differences between the experiences of boys and girls.

\subsection{Analysis}

The significant school experiences that students faced during their school careers were explored with open-ended questions and were seen as critical incidents in which the constructed pedagogical well-being becomes observable. These critical incidents were content analyzed using an abductive strategy and are here referred to as primary contexts of pedagogical well-being. The strategy of the content analysis of the questions was thus compatible with the idea of a hermeneutic circle; continuous dialogue was maintained between the theoretical assumptions and the phenomena manifested in the empirical data. Altogether 842 critical incidents from the pupils' school career were identified for further analysis. In total 186 answers were excluded from further analysis because there was either no answer in these specific questions or the response was too insufficient to interpret. The proportion of boys writing excluded answers was high (about threequarters).

In the first phase of analysis the data was coded into two basic hermeneutic categories A) emotionally burdening, and B) empowering school experiences, using a grounded strategy. After this, both basic categories were classified into the three exclusive main categories that constituted the primary contexts of pupils' pedagogical well-being: a) pupil-pupil interaction b) teacher-pupil interaction and c) academic and extra-curricular mastery. Categories resulting from the content analysis were validated by the research group at the end of each analysis phase (Miles \& Huberman, 1994; Yin, 1994). Finally, the timeline analysis was carried out to find out when both the positive and negative episodes had taken place. The statistical relationship between gender and primary contexts of pedagogical well-being was measured with a Chi-square test (significance level of $p<.05$ ). 
3 Results

\subsection{Timeframe of significant positive and negative school experiences}

Results suggested that critical incidents of pedagogical well being reported by the pupils were situated all along the timeline of their school career. Figure 1 shows that pupils reported both positive and negative episodes from the first to the ninth grade.

\section{[INSERT FIGURE 1. HERE]}

Figure 1. Pupils’ significant positive and negative school experiences during their school career from first to ninth grade

At the same time the results indicate that transitions within the pupils' school careers, such as the beginning of the school career, the shift from primary to middle school and the end of middle school, provided both a positive resource and a challenge for pupils’ pedagogical well-being. Transitions challenged pupils to monitor and reevaluate their capacity to cope with social, cognitive, as well as emotional challenges provided by the school.

\subsection{Primary contexts of pupils’ pedagogical well-being}

Further investigation of the critical incidents reported by the pupils showed that their experienced pedagogical well-being varied widely, ranging from anxiety and stress to empowerment and joy. Moreover they described a range of different kinds of events and episodes. Positive episodes causing satisfaction and engagement and negative episodes causing disappointment and distress were both reported by the pupils. In general it seems that pupils perceive social interactions with pupils, teachers and other members

of the school community as being both the most rewarding and at the same time the most problematic part of their school career. 
Pupils' pedagogical well-being was constructed in three primary contexts of everyday school practices. These primary contexts were: 1) the peer interaction, 2) the teacher-pupil interaction and 3) academic and extra-curricular mastery.

Table 1: Primary contexts of pupils’ experienced pedagogical well-being

\section{[INSERT TABLE 1 HERE]}

Table 1 demonstrates that pupils considered critical incidents in interaction with peers and teachers important contexts for their experienced pedagogical well-being. Critical incidents reported by the pupils also related to other pedagogical activities of school such as studying and special events. However common to the incidents was that they were primarily regulated by the quality of interaction between the members of the school community as perceived by the pupils.

\section{Peer interaction}

Both positive and negative episodes described by the pupils often related to success in social relationships with peers.

“There is no single experience, it's just that because we have been together for nine years with this class, studying is relaxed and fun. Presentations in the class don't make me so nervous anymore because we know each other so well. There is always something funny and new happening in our lessons. We are seldom bored." (Girl, positive episode in ninth grade)

The moments when the bullies were the most meanest - I remember all that ridicule and the worst moments I remember the best. (Girl, negative episode in sixth grade)

I was bullied (name calling, not physical). Name calling was irritating and nasty. The bullies thought I was different. (Boy, negative episode in seventh grade) 
Sometime in the middle of seventh grade three of my friends just started to hang more and more together, just the three of them. They had sleep-overs and did not invite me. They also ignored me in discussions during the breaks in school. I felt like an outsider. (Girl, negative episode in seventh grade)

Pupils emphasized the importance of having good friends and a benevolent class spirit as a positive source for their satisfaction and sense of belonging. In turn, a poor atmosphere, destructive frictions within the class community, a lack of friends and bullying were all reported to be burdensome and a cause for anxiety and stress. The importance of peer relations was also reflected in the emotional colouring of pupils' descriptions that ranged from joy and happiness to anger, disappointment, anxiety and sorrow, depending on the course of events. Forming and maintaining of friendships were emphasised as crucial elements for constructing a meaningful and satisfying school career by the pupils. Moreover, pupils identified functional relationships with the peers not only as an important resource for their experienced socio-psychological well-being but also for attaining learning motivation and outcomes.

\section{Teacher-pupil interaction}

Teacher-pupil interaction formed the smallest primary context of pupils' pedagogical well being (see Table 1). This suggests that pupils did not perceive encounters with teachers as significant as their interactions with peers in terms of their experienced pedagogical well-being. Although only about one fifth of the incidents described by the pupils fell into this category, nonetheless they were reported to have a long lasting and significant effect on the pupil's schooling, for example on studying motivation. The incidents related to teacher-pupil interaction were more often perceived as a cause for anxiety and stress than as a resource for satisfaction and empowerment by the pupils. The critical incidents within this category often related to pedagogically challenging social conflicts and the ways in which the conflicts were solved. Pupils' expected teachers to take an active role in solving the conflict. The incident was often 
perceived positively by the pupil if teachers used collaborative and activating methods to solve the problem. Moreover, characteristic for the incidents perceived positively by the pupils were that they received emotional support and constructive feedback from the teacher, and that the teacher promoted their sense of active agency and belonging in the class and school community. On the other hand if the social conflict was bypassed, left unnoticed or dominated by the teacher, pupils’ often considered the incidents negatively. Also unjustified and authoritarian behaviour that undermined pupil's agency was considered as a source of burden, anxiety and anger.

My first detention. I was daydreaming in class and was made to stay on detention, although the others did it too. I was angry at my teacher." (Boy, negative episode in first grade)

Teachers' gossiping about the pupils. It feels bad when you hear them saying something bad about someone and when you hear some bullshit about yourself too. Not a very nice feeling. (Girl, negative episode in eighth grade)

I had the most wonderful teacher who really cared about pupils' development and learning. (Girl, positive episode in first grade)

\section{Academic and extra-curricular mastery}

Table 1 shows that pupils also considered the pedagogical activities of the school as an important primary context in which their experienced pedagogical well-being was constructed. Within this category pupils reflected on their role as a student both in terms of studying activities and learning outcomes, as well as a participant in more informal school related events and activities such as sport games. Activities that were considered to be a positive resource for pupils' inspiration and sense of active learning agency were getting good grades (a formal school setting) and changes in school routine such as organizing school excursions or participating in the school play (a less formal school setting). 
We beat the neighbouring school 11-0. (Boy, positive episode second grade)

A school excursion in 9th grade was very pleasant. It was well organized. I thought that there should be more of these. (Boy, positive episode in ninth grade)

Correspondingly, failure in studies and poor grades were often reported to be a cause of anxiety and worry by the pupils'. Although pupils stressed the importance of getting good grades, only a few emphasized the importance of understanding and of learning itself.

Swedish lessons started. I thought: you can't learn this. Agony. (Boy, negative episode in seventh grade)

I was in danger of being held back in my class because I didn't study. I thought: now my friend is proceeding to ninth grade and I am left here. (Boy, negative episode in eighth grade)

Results suggested that pupil's self-efficacy beliefs, sense of academic mastery and socio-psychological well-being are constructed in a much wider context than classroom situations. Moreover, a sense of belonging in the school community, meaningful learning tasks and success in one's personal goals are complementary elements in the construction of pedagogical well-being for pupils.

Furthermore, the primary contexts of pedagogical well-being were cross-tabulated with the gender to find out if there was a statistically significant relationship between the pupils' perceptions of the primary contexts and gender. Investigations showed that there were differences in girls' and boys' positive and negative school experiences. These differences are presented in the Table 2. 
Table 2. Relation between gender and primary contexts of pedagogical well-being

\section{[INSERT TABLE 2 HERE]}

Girls emphasized successful peer group interactions, whereas boys more often described success or failure in school activities. In addition, boys perceived breaks in the school routine more positively and failure in studies more negatively than girls. Moreover, the proportion of boys was higher among the pupils who did not report any positive or negative critical incidents related to their school career in the survey. This failure to respond may be a reflection of differences between boys and girls in their attitudes towards school. A reason for a difference in attitude may be that although need for social acceptance and academic mastery is similar between boys and girls, the ways in which the needs are manifested differs.

\subsection{Conclusion}

Results showed that critical incidents for pedagogical well-being reported by the pupils were situated all along their school career. Pupils' experienced pedagogical wellbeing varied widely, ranging from anxiety and stress to empowerment and joy. The critical incidents were situated in events reported by pupils as ones that challenged them to negotiate their position as a member of the school community. In our explorations concerning gender and the primary context of pedagogical well-being, we found that the

girls and boys differed. In summary, success in both the social relationships and pedagogical goals seem to be a crucial precondition for pupils' sense of active learning agency in their school.

\section{Discussion}

In this article we have explored pupils' pedagogical well-being in the light of critical incidents along the school career described by the ninth graders. Even though critical incidents are only short episodes in a long school path we argue that analyzing them provides a substantial understanding of the key elements of pedagogical well-being and the processes through which it is constructed. 
Results suggested that pupils' experienced pedagogical well-being, both in terms of negative and positive experiences, is constructed and re-constructed in the everyday practices of schooling. A variety of episodes causing empowerment and satisfaction, and disappointment and anxiety, were reported by the pupils. Pupils' perceived the social interactions within the school community as being the most rewarding as well as the most problematic part of their school career. Accordingly it appears that pupil's pedagogical well-being is primarily regulated by the quality of interaction with peers, teachers and the school community as perceived by the pupils. However, the processes of constructing pedagogical well-being are often embedded implicitly in school practices and are thus easily left unnoticed by the school's professional community.

Our results showed that the peer interaction especially seems to play an important role in pupils' pedagogical well-being at school. Functional relationships with peers were reported to be a major source of satisfaction, while destructive friction in peer groups were considered a core source of anxiety and distress by the pupils. At the same time pupils' rarely reported encounters with teachers to be a source of empowerment and emotional support for them. This may be partly explained by features of teen culture that do not favour pupils who express highly positive attitudes towards school. Then again, it may also reflect the positive resource left unused by the teachers in teacher-pupil interactions for facilitating pupils' socio-psychological well-being and engagement in learning. If this resource is left unused in school development it is likely to further increase the negative influence of peer interactions on pupils. The significance of the peer interactions to pupils may provide new insights into simultaneously developing and supporting pupils' and teachers' pedagogical well-being at school. For example, collaborative investment in developing pupils' peer interactions within the class and school community is likely not only to promote the pupils' sense of belonging and satisfaction, but it may also provide a tool to promote more functional pupil-teacher relationships, hence facilitating teachers’ work-related well-being as well (Soini, Pyhältö, \& Pietarinen, 2008).

Our results also suggest that in addition to peer interactions, academic and extracurricular mastery play an important part in pupils' perceived pedagogical well-being at school, though critical incidents of pedagogical well-being were perceived differently by 
boys and girls. Boys emphasised interruptions in school routines, such as school excursions, as the most significant positive experiences in their school path. Conversely, failures in studying and transitions within the school path were perceived negatively more often by boys than girls. A reason for this may be that boys are more performanceoriented in the sense that they perceive competition, for example within studies or in extra-curricular activities, as more important than girls do. At the same time, not having positive school experiences and not describing them were more typical for boys than girls. This may be a reflection of the fact that some boys have a highly negative perception of school. Girls, on the other hand, emphasised the peer interaction as a primary context of their pedagogical well-being. Membership of peer groups and maintaining friendships were reported to be an important source of empowerment and satisfaction by girls more often than boys. Accordingly, girls seem to find more support for their pedagogical well-being from peers than boys do. On the other hand girls also reported anxiety and stress caused by the problems with peers more frequently than boys. Therefore the challenges of pedagogical well-being for girls in schools may lie with their peers, of both genders.

In summary, it can be argued that success in both studying and more general social goals seems to be a central precondition for pupils’ experienced pedagogical wellbeing. Consequently pedagogical well-being perceived by pupils may either hinder or promote the attainment of learning goals in a school context. From this perspective it appears that the primary contexts of pupils’ pedagogical well-being not only provide challenges, but also provide a positive resource for generating pupils' empowerment, satisfaction and studying drive. For example, the possibility and ability to use the social resources of the school environment incorporated with a sense of active learning agency may protect pupils from experiencing anxiety and emotional distress. This is, however, dependent on whether the interrelations between pupils' learning and well-being are seriously considered as a premise for school development. 


\section{Acknowledgements}

We wish to thank Annabel Battersby-Järvinen for the language revision. We also wish to thank the Finnish Ministry of Education and Finnish Work Environment Found for funding the research project Learning and Development in Comprehensive School.

\section{References}

Anderson, L.W., Jacobs, J., Schramm, S., \& Splittgerber, F. (2000). School transitions: beginning of the end or a new beginning? International Journal of Educational Research, 33(4), 325-339.

Antonovsky, A. (1987). Unraveling the mystery: How people manage stress and stay well. San Francisco: Jossey-Bass.

Antonovsky, A. (1993). The structure and properties of the sense of coherence scale. Social Science Medicine, 36(6), 725-734.

Boekaerts, M. (1993). Being concerned with well-being and with learning. Educational Psychologist, 28(2), 149-167.

Boekaerts, M., De Koning, E. \& Vedder, P. (2006). Goal-directed behaviour and contextual factors in the classroom: An innovative approach to the study of multiple goals. Educational Psychologist, 41(1), 33-51.

Butler, R., \& Shibaz, L. (2008). Achievement goals for teaching as predictors of students' perceptions of instructional practices and students' help seeking and cheating. Learning and Instruction, 18(5), 453-467. 
Bowen, G.L., Richman, J.M., Brewster, A., \& Bowen, N. (1998). Sense of school coherence, perceptions of danger at school, and teacher support among youth at risk of school failure. Child and Adolescent Social Work Journal, 15(4), 273-286.

Brown, A. (1992). Design Experiments: theoretical and methodological challenges in creating complex interventions in classroom setting. The Journal of the Learning Sciences, 2(2) 141-178.

Collins, A., Joseph, D., \& Bielaczyc, K. (2004). Design Research: Theoretical and methodological issues. The Journal of the Learning Sciences, 13(1), 15-42.

Deci, E.L., \& Ryan, R.M. (2002). Handbook of self-determination research. The University of Rochester Press.

De Corte, E. (2000, November). High-powered learning communities: a European perspective. Keynote address presented at the first Conference of the Economic and Social Research Council's Research Programme on Teaching and Learning, Leicester, UK.

Ellonen, N., Kääriäinen, J., \& Autio, V. (2008). Adolescent depression and school support: A multilevel analysis of a Finnish sample. Journal of Community Psychology, 36(4), 552-567.

Gillison, F., Standage, M., \& Skevington, S. (2008). Changes in quality of life and psychological need satisfaction following the transition to secondary school. British Journal of Educational Psychology, 78(1), 149-162.

Giota, J. (2006). Why am I in school? Relationships between adolescents' goal orientation, academic achievement and self-evaluation. Scandinavian Journal of Educational Research, 50(4), 441-461. 
Gregory, A., \& Ripski, M.B. (2008). Adolescent trust in teachers: Implications for behavior in the high school classroom. School Psychology Review, 37(3), 337-353.

Hakanen, J.J., Bakker, A.B., \& Schaufeli, W.B. (2005). Burnout and work engagement among teachers. Journal of School Psychology, 43(6), 495-513.

Hakkarainen, K., Palonen, T., Paavola, S., \& Lehtinen, E. (2004). Communities of networked expertise. Professional and educational perspectives. Oxford: Elsevier.

Hofer, M. (2007). Goal conflicts and self-regulation: A new look at pupils' off-task behaviour in the classroom. Educational Research Review, 2(1), 28-38.

Jindal-Snape D., \& Miller D. J. (2008). A Challenge of Living? Understanding the Psycho-social Processes of the Child during Primary-secondary Transition through Resilience and Self-esteem Theories. Educational Psychology Review, 20, 217-236.

Konu, A.I., Lintonen, T.P., \& Autio, V.J. (2002). Evaluation of well-being in schools - a multilevel analysis of general subjective well-being. School Effectiveness and School Improvement, 13, 187-200.

Krapp, A. (2005). Basic needs and the development of interest and intrinsic motivational orientations. Learning and Instruction, 15(5), 381-395.

Kristersson, P., \& Öhlund, L.S. (2005). Swedish upper secondary school pupils’ sense of coherence, coping resources and aggressiveness in relation to educational track and performance. Scandinavian Journal of Caring Science, 19(1), 77-84.

Lahelma, E. (2002). School is for meeting friends: secondary school as lived and remembered. British Journal of Sociology of Education, 23(3), 367-381. 
Lasky, S. (2005). A sociocultural approach to understanding teacher identity, agency and professional vulnerability in a context of secondary school reform. Teaching and Teacher Education, 21(8), 899-916.

Lazarus R.S., \& Lazarus, B.N. (1994). Passion and reason: making sense of our emotions. New York: Oxford University Press.

Lonka, K., Hakkarainen, K., \& Sintonen, M. (2000). Progressive inquiry learning for children -experiences, possibilities, limitations. European Early Childhood Education Association Journal, 8(1), 7-23.

Miles, M.B., \& Huberman, A.M. (1994). Qualitative data analysis. An expanded sourcebook. 2nd edition. Thousand Oaks: Sage.

Morrison, I., \& Clift, S.M. (2005). Mental health promotion through supported further education. The value of Antonovsky's salutogenic model of health. Health Education, 106(5), 365-380.

Nonaka, I., \& Nishiguchi, T. (2001). (Eds.) Knowledge emergence: social, technical and evolutionary dimensions of knowledge creation. Oxford University Press US.

Paavola, S., \& Hakkarainen, K. (2005). The knowledge creation metaphor - An emergent epistemological approach to learning. Science \& Education, 14(6), 535-557.

Pallant, J.F., \& Lae, L. (2002). Sense of coherence, well-being, coping and personality factors: further evaluation of the sense of coherence scale. Personality and Individual Differences, 33(1), 39-48.

Pelletier, L.G., Legault, L., \& Séguin-Lévesque, C. (2002). Pressure from above and from below as determinants of teachers' motivation and teaching behaviours. Journal of Educational Psychology, 94(1), 186-196. 
PISA, Program for International Student Assessment. Retrieved September 2008 from http://www.oecd.org/document/2/0,3343,en_32252351_32236191_39718850_1_1_1_1,0 $\underline{0 . h t m l}$

Huusko, J., Pietarinen, J., Pyhältö, K., \& Soini, T. (2007). [The preconditions for undivided basic education in comprehensive school]. Yhtenäisyyttä rakentava peruskoulu. Yhtenäisen perusopetuksen ehdot ja mahdollisuudet. Research in Educational Sciences 34. Turku: Finnish Educational Research Association.

Retelsdorf, J., Butler, R., Streblow, L., \& Schiefele, U. (2009). (in press). Teachers’ goal orientations for teaching: Associations with instructional practices, interest in teaching, and burnout. Learning and Instruction, (2009), doi:10.1016/j.learninstruc.2009.01.001.

Rimpelä, M., Kuusela, J., Rigoff, A-M., Saaristo, V., \& Wiss, K. (2008). [School Health Promotion Study. Grades 1.-6.] Hyvinvoinnin ja terveyden edistäminen peruskoulussa 2. Perusraportti kyselystä 1.-6. vuosiluokkien kouluille. Helsinki: Ministry of Education, National Research and Development Center for Wellfare and Health.

Rimpelä M., Rigoff A-M., Kuusela J., \& Peltonen H. (Eds.). (2007). [School Health Promotion Study. Grades 7.-9.] Hyvinvoinnin ja terveyden edistäminen peruskouluissa - perusraportti kyselystä 7.-9. vuosiluokkien kouluille. Helsinki: Ministry of Education \& National Research and Development Center for Wellfare and Health.

Ryan, R.M., \& Deci, E.L. (2001). Intrinsic and extrinsic motivations: Classic definitions and new directions. Contemporary Educational Psychology, 25(1), 68-81. 
Salomon, G. (1996). Unorthodox thoughts on the nature and mission of contemporary educational psychology. Educational Psychology Review, 8(4), 397-417.

Savolainen, A. (2001). [School as a work place. Pupils' and personel's perspectives.] Koulu työpaikkana. Työolojen itsearviointi ja kehittämistarpeet oppilaiden ja henkilöstön näkökulmasta. (Doctoral Dissertation, University of Tampere 2001). Acta Universitatis Tamperensis 830.

Schweinle, A. Turner, J.C., \& Meyer, D.K. (2008). Understanding young adolescents' optimal experiences in academic settings. The Journal of Experimental Education, 77(2), 125-143.

Seligman, M. E. P., \& Csikszentmihalyi M. (2000). Positive Psychology. An Introduction. American Psychologist, 55(1), 5-14.

Sheldon, K. M., \& King, L. (2001). Why positive psychology is necessary. American Psychologist, 56(3), 216-217.

Silins, H., \& Mulford, B. (2002). Schools as learning organisations. The case for system, teacher and student learning. Journal of Educational Administration, 40(5), 425-446.

Soini, T., Pyhältö, K., \& Pietarinen, J. (2008). (submitted). Pedagogical well-being. Reflecting learning and well-being in teachers' work. Teachers and Teaching: Theory and Practice.

Tarter, C.J., \& Hoy, W.K. (2004). A systems approach to quality in elementary schools. A theoretical and empirical analysis. Journal of Educational Administration, 42(5), 539-554. 
Tuominen-Soini, H., Salmela-Aro, K., \& Niemivirta, M. (2008). Achievement goal orientations and subjective well-being: A person-centred analysis. Learning and Instruction, 18(3), 251-266.

Torsheim, T., Aarø, L.E., \& Wold, B. (2001). "Sense of Coherence and school-related stress as predictors of subjective health complaints in early adolescence: Interactive, indirect or direct relationships". Social Science and Medicine, 53(5), 603-614.

Van Houtte, M. (2006). Tracking and teacher satisfaction: Role of study culture and trust. The Journal of Educational Research, 99(4), 247-254.

Van Petegem, K., Aelterman, A., Rosseel, Y., \& Creemers, B. (2006). Student perception as moderator for student wellbeing. Social Indicators Research, 83(3), 447-463.

Vedder, P., Boekaerts, M., \& Seegers, G. (2005). Perceived social support and well-being in school: the role of students' ethnicity. Journal of Youth and Adolescence, 34(3), 269-278.

Wenger, E. (1998). Communities of practice. Learning, meaning and identity. Cambridge: Cambridge University Press.

Wertsch, J. V. (1993). Voices of the mind: A sociocultural approach to mediated action. Cambridge, MA: Harvard University Press.

Yin, R.K. (1994). Case study research. Design and methods. 2nd edition. Thousand Oaks: Sage.

Zittoun, T. (2008). Learning through transitions: The role of institutions. European Journal of Psychology of Education, 23(2), 165-181. 
Zittoun, T., Duveen, G., Gillespie, A., Ivinson, G., \& Psaltis, C. (2003). The use of symbolic resources in developmental transitions. Culture \& Psychology, 9(4), 415448.

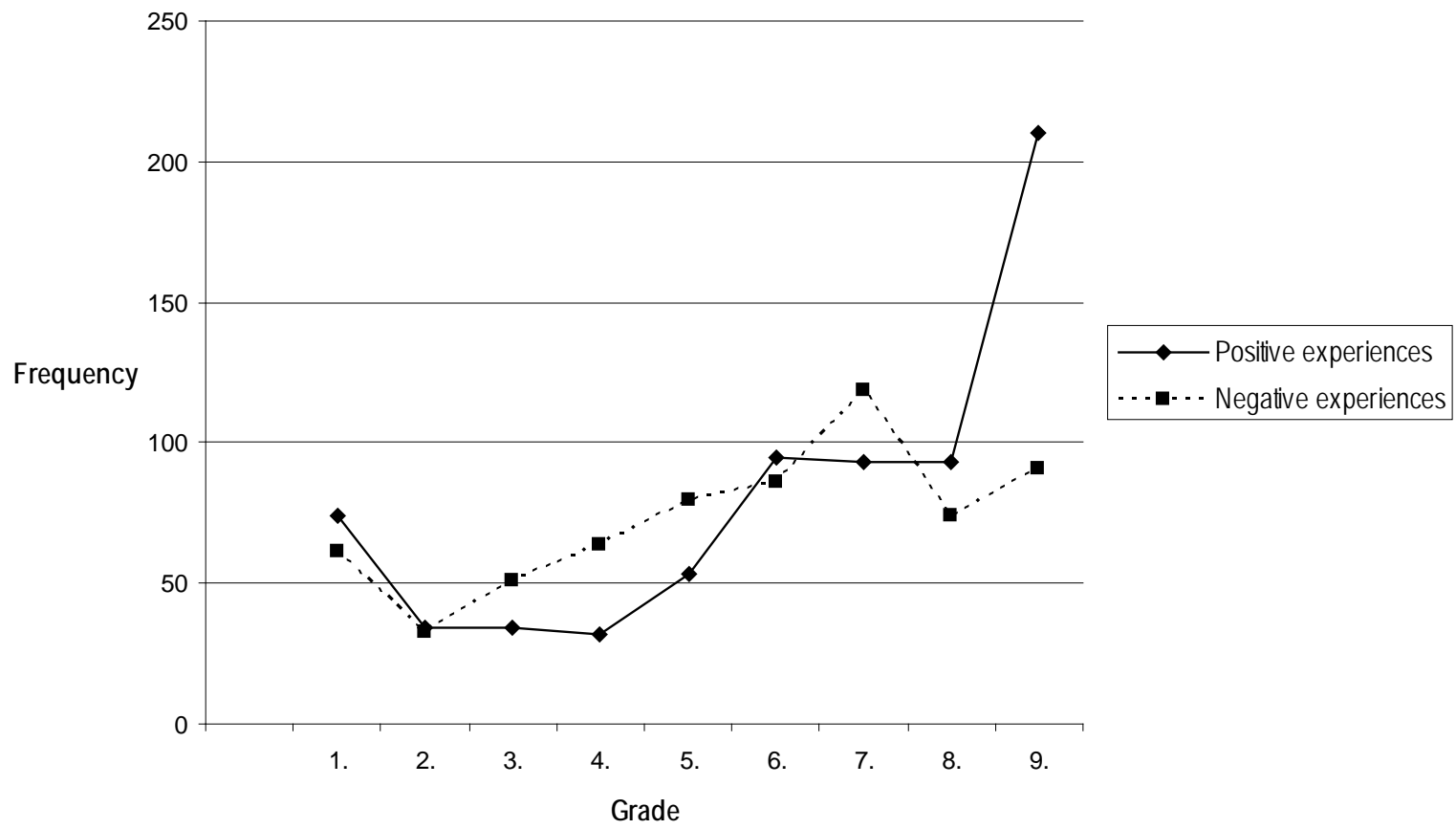

Figure 1. Pupils’ significant positive and negative school experiences during the school career from first to ninth grade 
Table 1. Primary contexts of pupils' experienced pedagogical well-being

\begin{tabular}{llll}
\hline & $\begin{array}{l}\text { Positive } \\
\text { experiences }\end{array}$ & $\begin{array}{l}\text { Negative } \\
\text { experiences }\end{array}$ & Total \\
\hline Pupil-pupil interaction $(f)$ & 174 & 172 & 346 \\
& $50 \%$ & $50 \%$ & $100 \%$ \\
Teacher-pupil interaction $(f)$ & $42 \%$ & $41 \%$ & 148 \\
& & & $100 \%$ \\
Academic and extra curricular mastery $(f)$ & 43 & 105 & 348 \\
& $10 \%$ & $71 \%$ & $100 \%$ \\
& & $25 \%$ & \\
Total & 202 & 146 & 842 \\
\end{tabular}


Table 2. Relationship between gender and primary contexts of pedagogical well-being

\begin{tabular}{|c|c|c|c|c|}
\hline & \multicolumn{2}{|c|}{ Positive experiences $^{\mathrm{a}}$} & \multicolumn{2}{|c|}{ Negative experiences ${ }^{\mathrm{aa}}$} \\
\hline & Girls & Boys & Girls & Boys \\
\hline \multirow[t]{2}{*}{ Pupil-pupil interaction (f) } & 116 & 58 & 104 & 68 \\
\hline & $67 \%$ & $33 \%$ & $61 \%$ & $39 \%$ \\
\hline \multirow[t]{2}{*}{ Teacher-pupil interaction ( $f$ ) } & 19 & 23 & 58 & 47 \\
\hline & $45 \%$ & $55 \%$ & $55 \%$ & $45 \%$ \\
\hline \multicolumn{5}{|l|}{ Academic and extra-curricular } \\
\hline \multirow[t]{2}{*}{ mastery ( $f$ ) } & 83 & 118 & 53 & 92 \\
\hline & $41 \%$ & $59 \%$ & $37 \%$ & $63 \%$ \\
\hline
\end{tabular}

